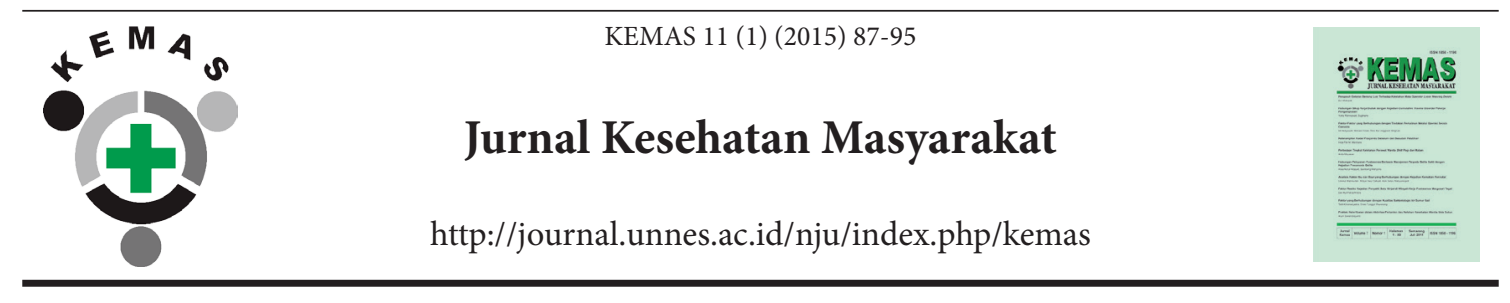

\title{
PAPARAN TIMBAL UDARA TERHADAP TIMBAL DARAH, HEMOGLOBIN, CYSTATIN C SERUM PEKERJA PENGECATAN MOBIL
}

\author{
Muliyadi $^{\circledR}$, H.J Mukono², Haryanto Notopuro ${ }^{3}$ \\ ${ }^{1}$ Magister Kesehatan Lingkungan, FKM, Universitas Airlangga, Surabaya, Indonesia \\ ${ }^{2}$ Departemen Kesehatan Lingkungan, FKM,Universitas Airlangga, Surabaya, Indonesia \\ ${ }^{3}$ Depatemen Biokimia, Fakultas Kedokteran, Universitas Airlangga, Surabaya, Indonesia
}

\section{Info Artikel}

Sejarah Artikel:

Diterima 23 Oktober 2014

Disetujui 25 November 2015

Dipublikasikan Juli 2013

Keywords:

Lead; Hemoglobin;

Cystatin C

DOI

http://dx.doi.org/10.15294/

kemas.v11i1.3519

\begin{abstract}
Abstrak
Timbal mempengaruhi sistem hematologis, saraf, urinaria, reproduksi, endokrin, dan jantung. Tujuan penelitian untuk menganalisis pengaruh timbal udara terhadap timbal darah dan pengaruh timbal darah terhadap hemoglobin, cystatin $\mathrm{C}$ serum dan keluhan kesehatan. Penelitian dilakukan pada tahun 2015. Jenis penelitian observasional (cross sectional study). Populasi penelitian yaitu kelompok penelitian dan pembanding dengan sampel 12 masing-masing kelompok. Analisis data menggunakan uji regresi linier ganda dan regresi logistik. Hasil penelitian menunjukkan ada pengaruh timbal udara dengan timbal darah $(\beta=0,667 ; p=0,000)$, ada pengaruh timbal darah dengan Hemoglobin $(\beta=-$ 0,609:p=0,008), ada pengaruh timbal darah dengan Cystatin $C(\beta=0,348: p=0,035)$ dan tidak ada pengaruh timbal darah dengan gangguan pencernaan $(\beta=0,004: p=0.990)$, ada pengaruh timbal darah dengan gangguan ginjal $(\beta=0,572: \mathrm{p}=0,038)$, ada pengaruh timbal darah dengan gangguan hematologis $(\beta=0,816: p=0,020)$, tidak ada pengaruh timbal darah dengan gangguan $\operatorname{SSP}(\beta=-0,022: p=0,944)$. Hasil penelitian menunjukkan bahwa timbal darah dipengaruhi oleh timbal di udara, hemoglobin dan cystatin $\mathrm{C}$ dipengaruhi oleh timbal darah serta gangguan hematologis dan gangguan ginjal dipengaruhi oleh timbal darah.
\end{abstract}

\section{EXPOSURE OF AERIAL LEAD TO BLOOD LEAD, HEMOGLOBIN, SERUM CYSTATIN C ON PAINTING CARS WORKER}

\begin{abstract}
Lead affects the haematological system, nervous, urinary, reproductive, endocrine, and cardiovascular. Research purposes to analyze the effect air lead to blood lead and blood lead effect on hemoglobin, serum cystatin $C$ and health complaints. The study was conducted in 2015. Type of study, observational (cross-sectional). Research population, Research and comparison with 12 samples each group. Data analysis using multiple linear and logistic regression. Results showed there effect air lead to blood lead $(\beta=0.667: p=0.000)$. There effect blood lead with Hemoglobin $(\beta=-0.609: p=0.008)$. there effect blood lead with Cystatin $C(\beta=0.348: p=0.035)$. There is no effect blood lead with digestive disorders $(\beta=0.004: p=0990)$. there effect blood lead with renal impairment $(\beta=0.572: p=0.038)$. there effect blood lead with haematological disorders $(\beta=0.816: p=0.020)$. There is no effect blood lead with CNS disorders $(\beta=-0.022: p=0.944)$. The results showed, blood lead is affected by lead air, Hemoglobin and Cystatin $C$ is affected by blood lead and hematological disorders and kidney disorders are affected by blood lead.
\end{abstract}

(C) 2015 Universitas Negeri Semarang 


\section{Pendahuluan}

Saat ini, pigmen yang mengandung $\mathrm{Pb}$ yang paling umum digunakan dalam cat meliputi $\mathrm{Pb}$ kromat $\left(\mathrm{PbCrO}_{4}\right), \mathrm{Pb}$ kromat molibdat $\left(\mathrm{Pb}_{2} \mathrm{Cr}_{2} \mathrm{Ho}_{2} \mathrm{O}_{11}\right)$, dan $\mathrm{Pb}$ sulfat $\left(\mathrm{PbSo}_{4}\right)$. $\mathrm{Pb}$ kromat dibuat dalam beragam struktur kristal untuk menghasilkan warna yang berbeda - beda, di antaranya "chrome yellow" (kuning tua), "middle chrome" (kuning kemerahan) dan "orange chrome" (oranye). $\mathrm{Pb}$ kromat molibdat menghasilkan pigmen merah cerah. Campuran $\mathrm{Pb}$ kromat dengan $\mathrm{Pb}$ sulfat dan senyawa lain menghasilkan banyak warna misalnya "primrose chrome" (kuning pucat kehijauan), "lemon chrome" (kuning kehijauan agak kemerahan), dan "chrome green" (campuran $\mathrm{Pb}$ kromat dan besi biru). Senyawa $\mathrm{Pb}$ juga dapat digunakan sebagai agen pengering dan katalis pada cat berdasar minyak, agar cat lebih cepat kering dan tersebar merata. Agen anti - korosi berdasar $\mathrm{Pb}$ kadang digunakan dalam cat yang berfungsi menghambat perkaratan pada permukaan logam, dengan umumnya berupa $\mathrm{Pb}$ tetroksida yang kadang disebut $\mathrm{Pb}$ merah atau minium. Senyawa penghambat korosi bebas $\mathrm{Pb}$ pun bisa didapatkan (Clark, 2009)

Salah satu bahan pencemar udara yang paling berbahaya adalah timbal. Timbal sering juga disebut dengan timah hitam $(\mathrm{Pb}$; lead). Timbal merupakan metal yang sangat berbahaya bagi kesehatan manusia yang berlangsung seumur hidup karena timbal berakumulasi dalam tubuh manusia. Dalam kasus paparan polusi timbal dalam dosis rendah sekalipun ternyata dapat menimbulkan gangguan pada tubuh tanpa menunjukkan gejala klinik (Naurot, 2006). Timbal juga terbukti meningkatkan jumlah kematian pada penderita penyakit jantung. Sampai saat ini belum dapat ditentukan berapa kadar terendah dari timbal dalam tubuh yang aman untuk kesehatan (Spivey, 2007).

Kota Surabaya merupakan kota terbesar ke dua setelah Jakarta hal ini tentunya akan meningkatkan jumlah kendaraan dan aktivitas di daerah Surabaya. Dengan meningkatnya jumlah kendaraan maka akan berdampak juga pada peningkatan industri atau jasa yang bergerak di bidang otomotif seperti bengkel pengecatan, dari hasil studi pendahuluan beberapa bengkel pengecatan mobil di Surabaya memiliki kondisi yang kurang baik dalam hal kepemilikan lubang udara seperti yang terjadi pada bengkel pengecatan mobil di lokasi penelitian sehingga hal ini menimbulkan potensi risiko terpapar bahan berbahaya yang ada pada bengkel pengecatan mobil yaitu salah satunya $\mathrm{Pb}$ yang bersumber dari pigmen Cat dan zat pengering cat.

Dari hasil survei pendahuluan diketahui bahwa pekerja pengecatan mobil di lokasi penelitian seluruhnya tidak menggunakan APD yang terstandar SNI sehingga sehingga hal ini berpotensi besar untuk keteraparan $\mathrm{Pb}$ yang dapat menimbulkan efek kronis hal ini di karenakan $\mathrm{Pb}$ yang masuk melalui saluran pernapasan dan saluran pencernaan dapat masuk ke dalam darah dan berikatan dengan eritrosit dan di metabolisme oleh tubuh ke dalam tubulus proksimal sehingga hal ini dapat menganggu fungsi ginjal itu sendiri, selain itu $\mathrm{Pb}$ yang masuk ke dalam darah akan menghambat sintesa heme sehingga akan mengurangi produksi $\mathrm{Hb}$ darah yang dapat berakibat pada munculnya gangguan kesehatan lainnya.

Banyak industri yang menggunakan $\mathrm{Pb}$ sebagai bahan baku misalnya industri battery dan aki serta banyak pula industri yang mengahasilkan produk yang mengandung $\mathrm{Pb}$ misalnya industri cat dan bahan pewarna lainnya (Sudarmaji, 2006). 11 sampel dari cat rumah yang di beli oleh salah seorang anggota organisasi Indonesia pada International POPs Elimination Network, dari took grosir di Indonesia yang bis diperoleh untuk publik pada tahun 2009. Pembelian selanjutnya, kaleng cat telah di kirim ke Cincinatti, dibuka, di aduk dan di cat dengan menggunakan kuas kayu yang belum di buka. Setiap alat pengaduk dan kuas yang di pakai hanya digunakan sekali. Kepingan cat dari daerah pengukuran kayu dipindahkan dengan hati-hati dengan menggunakan mata pisau, dan dikirim ke lab untuk di analisa. Cat tersebut di buat oleh empat perusahaan yang berbeda, kurang lebih satu sampel dari dua diantaranya di temukan memiliki kandungan timbal besar dari 1\%. Rata-rata timbal dari 11 sampel tersebut adalah $1.5 \%$. timbal di dalam cat sekitar $0.06 \%$ (Clark, 2009).

Ginjal memiliki kapasitas yang lebih 
tinggi untuk mengikat bahan kimia, oleh karena itu bahan kimia lebih banyak terkandung di dalam organ ginjal jika dibandingkan dengan organ lainnya (Mukono, 2010). Walaupun berat ginjal hanya sekitar $0,5 \%$ dari total berat badan, tetapi ginjal menerima darah sebesar 20\%- 25\% dari curah jantung melalui arteri renalis. Tingginya aliran darah yang menuju ginjal inilah yang menyebabkan berbagai macam obat, bahan kimia, dan logam-logam berat dalam sirkulasi sistemik dikirim ke ginjal dalam jumlah yang besar. Zat-zat toksik ini akan terakumulasi di ginjal dan menyebabkan kerusakan bagi ginjal itu sendiri.

Berdasarkan penelitian Rizkiyawati (2012), menyatakan bahwa ada hubungan antara kadar Timbal dalam darah dengan kadar Hemoglobin darah pada tukang becak di Pasar Mranggen Demak $(p=0,041)$. Penelitian Mifbakhudin (2007), juga menyatakan bahwa ada hubungan yang signifikan antara kadar Timbal dalam darah dengan kadar Hemoglobin $(\mathrm{p}<0,05)$.

Adapun Tujuan penelitian ini adalah untuk menganalisis pengaruh timbal udara terhadap timbal darah dan pengaruh timbal darah terhadap hemoglobin, cystatin C serum dan keluhan kesehatan.

\section{Metode}

Penelitian ini merupakan penelitian kuantitatif, dengan subyek penelitian pekerja bengkel pengecatan mobil dengan menggunakan uji laboratorium dan kuisoner dengan desain observasional dengan menggunakan pendekatan cross-sectional, Pengambilan sampel dalam penelitian ini menggunakan simple random sampling yang berarti memilih sampel secara acak, pengambilan sampel darah dilakukan oleh analis kesehatan dari laboratorium yang mengambil sampel darah pekerja administratif dan bagian bengkel masing-masing sebanyak 12 orang per kelompok, sampel yang diambil adalah yang memenuhi kriteria inklusi yaitu Laki - laki, Tidak memiliki riwayat DM, Tidak memiliki penyakit ginjal kronis sebelum di terima bekerja, Masa kerja $>5$ tahun, Tidak menggunakan APD, tidak ada riwayat penyakit anemia sebelum di terima bekerja, Tidak sedang dalam kondisi pendarahan (mimisan, batuk berdarah, kulit terluka, keluar darah dari organ vital).

Teknik pengumpulan data dengan cara wawancara menggunakan kuisoner tentang keluhan kesehatan, umur, kebiasaan merokok serta status gizi dan melakukan observasi tentang luas ventilasi, pencahayaan, luas ruangan bengkel dan administratrif serta pengambilan sampel darah oleh pihak laboratorium, yang kemudian sampel darah tersebut di analisis $\mathrm{Pb}$ darah, $\mathrm{Hb}$ darah dan kadar Cystatin C serum.

Sumber data dalam penelitian ini merupakan data primer keseluruhan, dimana data tersebut langsung di ambil pada saat penelitian berupa data umur, status gizi, kebiasaan merokok, luas ruangan, luas ventilasi dan pencahayaan serta sampel darah yang kemudian di analisis di laboratorium.

Cara analisis data menggunakan regresi linier ganda dan regresi logistik dengan menggunakan program pengolahan data. Adapun variabel yang akan diukur adalah Kadar $\mathrm{Pb}$ udara dengan menggunakan Gas Chromatography metode flame AAS (NIOSH methode 7082-2003), $\mathrm{Pb}$ darah diukur dengan menggunakan metode AAS, hemoglobin darah diukur menggunakan cyamethemoglobin dan cystatin $\mathrm{C}$ serum dengan menggunakan metode ELISA.

Pengukuran kadar $\mathrm{Pb}$ dalam darah dilakukan dengan cara yaitu sampel darah sebanyak $5 \mathrm{~mL}$ dimasukkan ke dalam cangkir porselin yang sudah ditimbang terlebih dahulu, kemudian ditambah $5 \mathrm{~mL}$ asam nitrat pekat dan asam pengabuan (campuran $25 \mathrm{~g}$ kalium sulfat dengan $100 \mathrm{~mL}$ asam nitrat pekat). Dipanaskan dalam furnace pada suhu $400^{\circ} \mathrm{C}$, sampai diperoleh serbuk berwarna putih, kemudian ditambahkan dengan aquades sebanyak $10 \mathrm{~mL}$, kemudian dipanaskan berulang ulang sampai asam nitratnya habis. Kandungan timbal dalam darah dapat dibaca dengan menggunakan AAS.

Pengukuran kadar $\mathrm{Hb}$ darah dengan metode cyanmethemoglobin. Dibuat larutan Drabkin's dengan mencampur: Sodium bikarbonat (Na2CO3) 1,0 g, Potassium Cyanida (KCN) 50,0 mg, Potassium ferricyanida (K3Fe(CN)6) 200,0 mg. Dicampur dengan air suling sampai mencapai $1000 \mathrm{~mL}$. Pengukuran $\mathrm{Hb}$ dengan alat spektrofotometri, 
sebagai berikut: larutan Drabkin's sebanyak 5 $\mathrm{mL}$ dimasukkan ke dalam kuvet yang sudah bersih dan kering, lalu ditambahkan sampel darah sebanyak $0,02 \mathrm{~mL}$ yang diambil dengan menggunakan pipet sahli dan dibiarkan selama 3 menit. Dilihat dengan spektrofotometri pada panjang gelombang $540 \mathrm{~nm}$. Larutan Drabkin's digunakan sebagai blanko sampai menunjukkan angka 100. Hasil pembacaan pada jarum penunjuk dikalikan dengan 36,8 (g $\mathrm{Hb} / \mathrm{dl})$.

Pemeriksaan Cystatin C serum. Pemeriksaan ini merupakan pemeriksaan kuantitatif secara sandwich enzyme immunoaAASy. Antibodi monoklonal spesifik untuk CysC sebelumnya dilapisi ke microplate. Standar dan sampel dipipet ke dalam well jika terdapat $\mathrm{Cys} \mathrm{C}$ maka akan diikat oleh antibodi. Setelah pencucian substansi yang tidak berikatan, sebuah enzim pengikat antibodi monoclonal spesifik/enzyme-linked monoclonal antibody specific untuk CysC ditambahkan ke dalam well. Kemudian dilakukan lagi pencucian untuk membuang reagen antibodi-enzim yang tidak berikatan, lalu larutan substrat ditambahkan ke dalam well dan warna yang terbentuk secara proporsional menunjukkan jumlah CysC yang berikatan pada tahap awal. Pembentukan warna dihentikan dan intensitas warna diperiksa.

Pemeriksaan imunologi mengukur CysC ditemukan oleh Loberg dan Grubb pada tahun 1979 dengan metode enzyme-amplified single radial immunodiffusion. Metode ini mempunyai batas deteksi $30 \mu \mathrm{g} / \mathrm{L}$. Metode lainnya untuk mendeteksi CysC ditemukan beberapa tahun kemudian, berdasarkan radio, flourescent, dan enzymatic immunoassay. Batas pemeriksaan untuk metode ini adalah antara 0,13-1,9 $\mu \mathrm{g} / \mathrm{L}$ nilai referensi diidentifikasi dari laki-laki dan perempuan. Metode awal pemeriksaan CysC ini termasuk radial immunodifusi dan enzim immunoassay membutuhkan waktu yang lama, dan presisinya rendah. Metode terakhir yang ditemukan adalah automated homogeneous immunoassay menggunakan latex atau partikel polystyrene yang dilapisi dengan antibodi CysC spesifik. Ada dua versi berbeda untuk metode latex immunoassay, pertama berdasarkan metode particle-enhanced turbidimetric immunoassay/PETIA) yang ditemukan oleh Kyhse- Anderson et al pada tahun 1994, dan metode kedua berdasarkan nefelometri (particle-enhanced nephelometric immunoassay/PENIA) yang diperkenalkan oleh Dade Behring GmBh tahun 1997.

\section{Hasil dan Pembahasan}

Pengaruh paparan $\mathrm{Pb}$ di udara terhadap kadar $\mathrm{Pb}$ darah dan pengaruh kadar $\mathrm{Pb}$ darah terhadap Hemoglobin darah dan Cystatin C serum yang dianalisis dengan menggunakan uji regresi linier dengan hasil sebagai berikut.

Berdasarkan Tabel 1 menunjukkan bahwa ada pengaruh antara kadar $\mathrm{Pb}$ di udara terhadap kadar $\mathrm{Pb}$ darah $(\beta=0,667 ; \mathrm{p}=0,000)$. Dan kebiasaan merokok juga berpengaruh terhadap kadar $\mathrm{Pb}$ darah $(\beta=0,620 ; \mathrm{p}=0,000)$. Jadi dapat dikatakan bahwa semakin tinggi paparan $\mathrm{Pb}$ di udara maka semakin tinggi pula

Tabel 1. Pengaruh Paparan $\mathrm{Pb}$ di Udara terhadap Kadar Pb Darah dan Pengaruh Kadar Pb darah terhadap Hemoglobin Darah dan Cystatin C Serum

\begin{tabular}{lcccccc}
\hline & \multicolumn{2}{c}{ Pb darah } & \multicolumn{2}{c}{$\begin{array}{c}\text { Hemoglobin } \\
\text { darah }\end{array}$} & \multicolumn{2}{c}{ Cystatin C serum } \\
\cline { 2 - 7 } & $\beta$ & $\mathrm{p}$ & $\beta$ & $\mathrm{p}$ & $\mathrm{B}$ & $\mathrm{P}$ \\
\hline Pb udara & 0.667 & 0.000 & & & & \\
Kebiasaan merokok & 0.620 & 0.000 & & & & \\
Status gizi & 0.189 & 0.133 & & & & \\
Umur & -0.109 & 0.359 & & & & 0.035 \\
Pb darah & & & -0.609 & 0.008 & 0.348 & 0.118 \\
Kebiasaan merokok & & & 0.203 & 0.360 & -0.264 & 0.001 \\
Status gizi & & & -0.041 & 0.831 & 0.532 & 0.001 \\
Umur & & & -0.382 & 0.034 & 0.327 & 0.017 \\
\hline
\end{tabular}

Sumber : Data Primer

${ }^{* *} \mathrm{p}<0,01$ (sangat signifikan) ${ }^{*} \mathrm{p}<0,05$ (signifikan) 
kadar $\mathrm{Pb}$ darah dan semakin tinggi jumlah rokok yang dihisap perhari dalam setahun maka semakin tinggi pula kadar $\mathrm{Pb}$ darah pada pekerja bengkel pengecatan di Surabaya. Umur dan status gizi tidak mempengaruhi kadar $\mathrm{Pb}$ darah pekerja bengkel pengecatan di Surabaya.

Hal ini sejalan dengan penelitian yang dilakukan oleh Ayub (2005), yang menunjukkan bahwa ada hubungan bermakna antara $\mathrm{Pb}$ darah dengan $\mathrm{Pb}$ di udara $(\mathrm{r}=0.815, \mathrm{p}<0.05)$. Analisa regresi linear seterusnya mendapati $\mathrm{Pb}$ darah meningkat sebanyak $0.22 \mu \mathrm{g} / \mathrm{dl}$. $\mathrm{Pb}$ di udara menyumbangkan sebanyak $66.3 \%$ variasi di dalam $\mathrm{Pb}$ darah. Juga sejalan dengan penelitian Rustanti (2011), yang menyatakan bahwa ada hubungan antara kebiasaan merokok dengan kadar $\mathrm{Pb}$ darah dengan nilai $\mathrm{p}=0,031$ dengan arah hubungan positif. dan berdasarkan hasil penelitian yang di lakukan oleh Hasan Dkk, 2013 menunjukkan bahwa kadar $\mathrm{Pb}$ darah juga dipengaruhi kebiasaan merokok dengan nilai $\mathrm{p}=0,03$

Hasil penelitian menunjukkan kadar $\mathrm{Pb}$ di udara di bagian pengecatan lebih tinggi di bandingkan dengan bagian administrasi dan bahkan melebihi NAB yang telah di tetapkan oleh menteri tenaga kerja melalui permenakertrans, no. 13/MEN/X/2011 tentang Nilai Ambang Batas Faktor Fisika dan Faktor Kimia di Tempat Kerja yaitu 0,05 ppm untuk $\mathrm{Pb}$ udara, dengan paparan $\mathrm{Pb}$ di udara bagian pengecatan 0,065372 lebih besar daripada bagian administrasi yaitu hanya 0.000522 , penelitian ini sejalan dengan penelitian yang di lakukan oleh Yuliningsih (2011), yang menyatakan bahwa terdapat perbedaan kadar $\mathrm{Pb}$ udara antara bengkel resmi dengan bengkel non resmi dengan nilai $p=0,046$. dan penelitian ini juga sejalan dengan penelitian Laila Faizah yang meneliti di pabrik sel aki yang sangat rentan akan paparan $\mathrm{Pb}$ di mana $\mathrm{Pb}$ udara berbeda jauh pada antara sebelum aktivitas bekerja dilakukan yaitu $0,20 \mathrm{Ppm}$ di bandingkan dengan setelah di mulai bekerja yaitu 0,52 Ppm. Dari hasil penelitian di atas menyatakan bahwa daerah yang terpapar $\mathrm{Pb}$ akan memiliki $\mathrm{Pb}$ udara yang lebih tinggi di bandingkan dengan daerah yang tidak terpapar $\mathrm{Pb}$.

Tingginya $\mathrm{Pb}$ di udara bagian pengecatan ini di karenakan penggunaan cat yang mengandung $\mathrm{Pb}$ sebagai pigmen pewarna dalam cat seperti $\mathrm{Pb}$ kromat $\left(\mathrm{PbCrO}_{4}\right), \mathrm{Pb}$ kromat molibdat $\left(\mathrm{Pb}_{2} \mathrm{Cr}_{2} \mathrm{Ho}_{2} \mathrm{O}_{11}\right)$, dan $\mathrm{Pb}$ sulfat $\left(\mathrm{PbSo}_{4}\right)$. Berdasarkan penelitian yang dilakukan oleh International Organization Promoting Safe Chemical Policies and Practices that Protect Human Health and the Environment yang menyatakan bahwa Sekitar 77\% dari sampel cat dijual di Indonesia setelah diuji mengandung $\mathrm{Pb}$ di atas $90 \mathrm{ppm}$ dengan kadar rata - rata yang ditemukan yaitu 17.300 ppm, atau hampir 200 kali lipat dari tingkat yang disarankan yaitu 90 ppm.

Terjadinya pencemaran udara dapat melalui beberapa proses seperti atrisi, penguapan dan pembakaran, pencemaran udara di bengkel pengecatan merupakan akibat dari proses pengecatan kendaraan dalam ruangan sehingga ruangan administrasi yang tidak terkait secara langsung dengan aktivitas pengecatan ini tidak terpapar oleh $\mathrm{Pb}$ yang berasal dari cat.

Berdasarkan penelitian ini menunjukkan bahwa kadar $\mathrm{Pb}$ darah pekerja bagian pengecatan lebih tinggi dibandingkan dengan pekerja bagian administrasi. Dengan rata-rata kadar $\mathrm{Pb}$ darah kelompok terpapar 11,20 $\mu \mathrm{g} /$ dl sedangkan pada kelompok tidak terpapar $8,25 \mu \mathrm{g} / \mathrm{dl}$ dan sebagian besar kadar $\mathrm{Pb}$ darah kelompok terpapar melebihi standar yang telah ditentukan yaitu $10 \mu \mathrm{g} / \mathrm{dl}$. Menurut Palar (2012), Peningkatan $\mathrm{Pb}$ darah diakibatkan oleh keterpaparan $\mathrm{Pb}$ udara, ini di karenakan $\mathrm{Pb}$ yang masuk kedalam darah melalui saluran pernapasan, kulit dan ingesti akan terakumulasi $95 \%$ ke darah dan absorpsi $\mathrm{Pb}$ terbesar ialah melaui pernapasan sehngga $\mathrm{Pb}$ di udara menyumbang sebagian besar $\mathrm{Pb}$ di dalam darah.

Berdasarkan tabel 1 dapat diketahui bahwa ada pengaruh antara kadar $\mathrm{Pb}$ darah dan umur dengan kadar hemoglobin darah dengan pengaruh $\mathrm{Pb}$ terhadap hemoglobin $(\beta=-0,609 ; p=0,008)$, dan pengaruh umur terhadap $\mathrm{Pb}$ darah $(\beta=-0,382 ; \mathrm{p}=0,034)$. Jadi dapat diketahui bahwa melalui kadar $\mathrm{Pb}$ darah bahwa semakin tinggi paparan $\mathrm{Pb}$ udara maka semakin rendah kadar hemoglobin darah dan semakin tua umur maka semakin rendah kadar hemoglobin darah.

Berdasarkan penelitian ini menunjukkan 
bahwa kadar hemoglobin darah pekerja bagian pengecatan lebih rendah di bandingkan dengan pekerja bagian administrasi. Dengan rata-rata kadar hemoglobin darah kelompok terpapar $12,97 \mathrm{~g} / \mathrm{dL}$, sedangkan pada kelompok tidak terpapar 14,77 g/dL dan sebagian besar kadar Hemoglobin darah kelompok terpapar kurang dari syarat Hemoglobin darah normal yaitu $13,2-17,3 \mathrm{~g} / \mathrm{dL}$.

Hal ini sejalan dengan penelitian yang di lakukan oleh Riskiawati (2012), yang menunjukkan bahwa ada hubungan bermakna antara $\mathrm{Pb}$ darah dengan kadar hemoglobin darah dengan nilai $\mathrm{p}=0,041$ dan ada hubungan antara $\mathrm{Pb}$ darah dengan umur dengan nilai $\mathrm{p}=0,036$. Timbal dalam darah akan berikatan dengan eritrosit, sehingga dapat menghmbat aktivitas enzim oksidase (Yulaipi, 2013). Adanya $\mathrm{Pb}$ dalam darah dapat mengikat ALAD (aminolevulenic acid dehidrase), suatu enzim yang di perlukan dalam metabolisme pembentukan sel darah merah dan membuangnya lewat urine. Itulah sebabnya semakin tinggi kadar $\mathrm{Pb} . \mathrm{B}$ maka semakin tinggi pula kadar ALA dalam urine (ALA-U) dan semakin rendah ALAD dalam darah, sehingga banyaknya $\mathrm{Pb}$ darah bertanggung jawab atas kekurangan hemoglobin dalam darah. Keberadaan timbel dalam tubuh dapat mengganggu sistem hemopoitik pada sintese heme melalui tiga mekanisme, yakni mengganggu penyatuan Glycine dan Succinyl Co-Enzyme A, melalui depresi terhadap delta- ALAD, dan melalui gangguan terhadap enzim Ferrochelatase yang berfungsi melekatkan besi (Fe) terhadap protoporphyrin yang kemudian menjadi heme sebagai bagian dari hemoglobin (Malaka, 2012), dan hal ini juga di ungkapkan oleh Lubis (2013), yang menyatakan bahwa timbal juga menghambat enzim asam $\delta$-aminolevulinat dehidrase dan ferrokelatase, sehingga enzim asam $\delta$-aminolevulinat dehidrase tidak dapat mengubah porfobilinogen, akibatnya besi tidak dapat memasuki siklus protoporfirin menyebabkan berkurangnya sintesis heme sehingga terjadi anemia.

Berdasarkan tabel 1 dapat diketahui bahwa ada pengaruh antara kadar $\mathrm{Pb}$ darah, umur dan status gizi dengan kadar Cystatin $\mathrm{c}$ serum darah dengan pengaruh $\mathrm{Pb}$ terhadap cystatin c serum $(\beta=0,348 ; p=0,035)$, dan pengaruh status gizi terhadap Cystatin $C$ serum $(\beta=0,532 ; p=0,001)$ serta pengaruh umur terhadap cystatin $C$ serum $(\beta=0,327 ; p=0,017)$ Jadi dapat diketahui bahwa semakin tinggi kadar $\mathrm{Pb}$ darah maka semakin tinggi pula kadar cystatin $\mathrm{C}$ serum dan semakin semakin tinggi indeks massa tubuh semakin tinggi pula kadar cystatin $\mathrm{C}$, serta semakin tua umur maka semakin tinggi juga kadar cystatin $\mathrm{C}$ serum.

Organ ginjal memiliki kapasitas lebih tinggi dalam mengikat bahan kimia, sehingga bahan kimia lebih banyak terkonsentrasi pada organ ginjal jika dibandingkan dengan organ lainnya (Mukono, 2010). Walaupun berat ginjal hanya sekitar $0,5 \%$ dari total berat badan, tetapi ginjal menerima darah sebesar 20\%- $25 \%$ dari curah jantung melalui arteri renalis. Tingginya aliran darah yang menuju ginjal inilah yang menyebabkan berbagai macam obat, bahan kimia, dan logam- logam berat dalam sirkulasi sistemik dikirim ke ginjal dalam jumlah yang besar. Zat-zat toksik ini akan terakumulasi di ginjal dan menyebabkan kerusakan bagi ginjal itu sendiri. Oleh sebab itu, $\mathrm{Pb}$ yang masuk kedalam darah yang kemudian di eksresikan melalui ginjal akan terakumulasi menahun di dalam ginjal, sehingga dapat menyebabkan terjadinya kerusakan tubulus proksimal sehingga meningkatkan Cystatin C serum. Menurut Palar (2012), pemaparan tinggi terhadap senyawa $\mathrm{Pb}$ anorganik dapat merusak ginjal, yaitu terjadinya kerusakan pada tubulus proksimal ginjal, sedang pengaruh selanjutnya pada pemaparan kadar tinggi dan waktu yang lama adalah terjadinya interstitial fibrosis, sclerosis dari pembuluh dan atrofi glomerulus.

Berdasarkan penelitian ini menunjukkan bahwa kadar cystatin $\mathrm{C}$ serum pekerja bagian pengecatan lebih tinggi di bandingkan dengan pekerja bagian administrasi. Dengan rata-rata kadar cystatin C serum kelompok terpapar 1,08 $\mathrm{mg} / \mathrm{L}$ sedangkan pada kelompok tidak terpapar $0,84 \mathrm{mg} / \mathrm{L}$ dan sebagian besar kadar cystatin C serum darah kelompok terpapar melebihi standar yang telah ditentukan yaitu $>0,53-$ 1,01 mg/L. Menurut Palar (2012), Pemaparan tinggi terhadap senyawa $\mathrm{Pb}$ anorganik dapat merusak ginjal, yaitu terjadinya kerusakan pada tubulus proksimal ginjal, sedang pengaruh selanjutnya pada pemaparan kadar 
tinggi dan waktu yang lama adalah terjadinya interstitial fibrosis, sclerosis dari pembuluh dan atrofi glomerulus. Organ ginjal memiliki kapasitas yang lebih tinggi dalam mengikat bahan kimia, sehingga bahan kimia lebih banyak terkonsentrasi pada organ ginjal jika dibandingkan dengan organ lainnya.

$\mathrm{Hal}$ ini sejalan dengan penelitian yang dilakukan oleh Dellyani (2010), ternyata paparan $\mathrm{Pb}$ secara inhalasi selama 30 hari dapat menyebabkan kerusakan tubulus proksimal ginjal mencit Balb/c secara mikroskopis, berupa penyempitan dan penutupan lumen tubulus proksimal pada kelompok P1, P2, P3 dibandingkan dengan kelompok perlakuan control $(\mathrm{p}<0,05)$. Hal ini sesuai dengan teori bahwa proses ekskresi timbal yang berlangsung di ginjal dapat menimbulkan dampak buruk bagi ginjal itu sendiri.

Hal ini juga sejalan dengan penelitian Bashir et al yang menyatakan bahwa ada perbedaan yang signifikan kadar cystatin C antara kelompok obese, overweight dan kelompok kontrol baik pada Laki-laki maupun Perempuan dimana kadar cystatin C lebih tinggi pada kelompok obese dibandingkan kelompok overweight dan kelompok kontrol. Pada obesitas berdasarkan IMT diketahui bahwa adiposity tidak hanya berfungsi sebagai tempat untuk penyimpanan triacyglycerol, tetapi mampu memproduksi dan mensekresikan sejumlah protein termasuk cystatin C yang memengaruhi berbagai proses fisiologis.

Kelompok obesitas lebih berisiko terkena gangguan ginjal dibandingkan kelompok normoweight. Peningkatan risiko Early Stage Renal Disease (ESRD) pada BMI yang tinggi dan obesitas adalah lima kali lebih lebih tinggi dibandingkan individu dengan berat badan normal. Lemak visceral, resistensi insulin dan inflamasi berkorelasi kuat dengan terjadinya CKD dan ESRD pada obesitas (Zoccali, 2010). Penelitian sebelumnya di University of California, San Fransisco juga menemukan bahwa ada hubungan yang kuat antara obesitas dengan perjalanan terjadinya CKD atau ESRD. Mereka meyimpulkan bahwa risiko gagal ginjal pada responden overweight hampir dua kali lebih besar daripada responden berat badan normal dan responden yang obese dengan IMT $40 \mathrm{~kg} / \mathrm{m}^{2}$ atau lebih memiliki risiko tujuh kali lebih besar menderita gagal ginjal.

Nurbaya (2010), dalam penelitiannya menyebutkan bahwa pekerja dengan status gizi lebih mempunya kadar timah hitam lebih besar dengan nilai $\mathrm{p}=0,001$. Naour (2009), dalam penelitiannya pada subyek obesitas (IMT : $34,7 \pm 0,29 \mathrm{~kg} / \mathrm{m}^{2}$ ) menemukan bahwa level cystatin C meningkat pada obesitas. Cystatin C mRNA di ekspresikan dalam jaringan subkutan dan adiposa omentum dua kali lipat lebih tinggi dibandingkan jaringan non adiposa. Peningkatan ini bisa muncul dari adiposit yang membesar dan atau dari sel SVF termasuk makrofag yang mengekspresikan cystatin C mRNA dan menyusup pada jaringan adiposa. Mereka menyimpulkan bahwa cystatin C menambah daftar faktor baru molekul bioaktif yang disekresikan oleh jaringan adiposa untuk implikasi obesitas dan komplikasi terkait obesitas. Pada penelitian terhadap populasi dewasa yang menderita overweight dan obesitas di Amerika Serikat oleh Muntner (2008), juga didapatkan hubungan yang kuat antara IMT dengan peningkatan kadar cystatin $\mathrm{C}$ sebagai biomarker ESRD.

Walaupun berat ginjal hanya sekitar $0,5 \%$ dari total berat badan, tetapi ginjal menerima darah sebesar 20\%- 25\% dari curah jantung melalui arteri renalis. Tingginya aliran darah yang menuju ginjal inilah yang menyebabkan berbagai macam obat, bahan kimia, dan logam- logam berat dalam sirkulasi sistemik dikirim ke ginjal dalam jumlah yang besar. Zat-zat toksik ini akan terakumulasi di ginjal dan menyebabkan kerusakan bagi ginjal itu sendiri.Oleh sebab itu $\mathrm{Pb}$ yang masuk ke dalam darah yang kemudian di eksresikan melalui ginjal akan terakumulasi menahun di dalam ginjal sehingga dapat menyebabkan terjadinya kerusakan tubulus proksimal sehingga meningkatkan Cystatin C serum.

Pengaruh kadar $\mathrm{Pb}$ darah terhadap keluhan kesehatan di analisis menggunakan uji statistik regresi logistik. Analysis pengaruh kadar $\mathrm{Pb}$ darah terhadap keluhan kesehatan yang meliputi gangguan pencernaan, gangguan sistem saraf, gangguan hematologis dan gangguan ginjal dapat dilihat pada tabel 2

Berdasarkan tabel 2, ada pengaruh keluhan gangguan ginjal $(\beta=0,572 ; p=0,038)$ dan hematologis $(\beta=0,816 ; \mathrm{p}=0,020)$ dengan 
Tabel 2 Analisis Pengaruh Kadar Pb Darah terhadap Keluhan Kesehatan Pekerja Pengecatan Mobil di Surabaya tahun 2015

\begin{tabular}{lcccccccc}
\hline \multirow{2}{*}{ Variabel } & \multicolumn{2}{c}{$\begin{array}{c}\text { Gangguan } \\
\text { Pencernaan }\end{array}$} & \multicolumn{2}{c}{ Gangguan Ginjal } & \multicolumn{2}{c}{$\begin{array}{c}\text { Gangguan } \\
\text { Hematologis }\end{array}$} & \multicolumn{2}{c}{$\begin{array}{c}\text { Gangguan Sistem } \\
\text { Saraf Tepi }\end{array}$} \\
\cline { 2 - 9 } & $\boldsymbol{\beta}$ & $\mathbf{P}$ & $\mathbf{B}$ & $\mathbf{P}$ & $\boldsymbol{\beta}$ & $\mathbf{p}$ & $\mathbf{B}$ & $\mathbf{P}$ \\
\hline $\begin{array}{l}\text { Kadar } \mathrm{Pb} \\
\begin{array}{l}\text { Darah } \\
\text { Kebiasaan }\end{array}\end{array}$ & 0.004 & 0.990 & 0.572 & $0.038^{*}$ & 0.816 & $0.020^{*}$ & -0.022 & 0.944 \\
$\begin{array}{l}\text { Merokok } \\
\text { Status gizi }\end{array}$ & 0.005 & 0.511 & -0.004 & 0.539 & -0.011 & 0.119 & 0.000 & 0.902 \\
Umur & & & & & & & & \\
\hline
\end{tabular}

Sumber : Data Primer

${ }^{* *} \mathrm{p}<0,01$ (sangat signifikan) ${ }^{*} \mathrm{p}<0,01$ (signifikan)

kadar $\mathrm{Pb}$ darah sedangkan untuk keluhan gangguan pencernaan dan SSP tidak ditemukan pengaruh oleh kadar $\mathrm{Pb}$ darah, umur, status gizi dan kebiasaan merokok.

Berdasarkan penelitian ini menunjukkan bahwa sebagian besar keluhan pada kelompok terpapar adalah gangguan gangguan ginjal dan hematologis (75,00\%), sedangkan pada kelompok tidak terpapar relatif tidak menunjukkan adanya keluhan kesehatan yang siginifikan karena prosentasenya tidak lebih besar dari $50 \%$.

\section{Penutup}

Timbal di udara bagian pengecatan memiliki kadar yang lebih tinggi yaitu 0,000522 ppm, sedangkan kadar $\mathrm{Pb}$ di ruang pengecatan mobil sebesar 0,065372 ppm, dan kadar $\mathrm{Pb}$ darah kelompok terpapar lebih tinggi dengan rerata $11,20 \mathrm{ppm}$ di bandingkan dengan kelompok tidak terpapar yaitu 8,25 ppm begitu pula kadar Hemoglobin pada kelompok terpapar yaitu lebih rendah dengan rerata pada kelompok terpapar yaitu $12,97 \mathrm{~g} / \mathrm{dL}$ dibandingkan pada kelompok tidak terpapar $14,77 \mathrm{~g} / \mathrm{dL}$ dan kadar Cystatin C serum pada kelompok terpapar lebih besar dengan rerata 1,08 dan kelompok tidak terpapar 0,84 dan berdasarkan analisis data diperoleh hasil yaitu Kadar Timbal darah dipengaruhi oleh kadar Timbal diudara, kadar Hemoglobin dan Cystatin C serum di pengaruhi oleh kadar Timbal darah dan keluhan kesehatan yang di pengaruhi oleh kadar Timbal dalam darah adalah gangguan hematologis dan gangguan ginjal pada pekerja di bengkel pengecatan.

\section{Ucapan Terima Kasih}

Ucapan terima kasih kepada Allah SWT atas rahmat, karunia dan Hidayahnya sehingga penulis dapat menyelesaikan penelitian ini. Ucapan terimakasih dan penghargaan setinggitingginya kepada pekerja bengkel pengecatan mobil yang telah bersedia menjadi responden dalam penelitian ini.

\section{Daftar Pustaka}

Ayub, Ismail.. 2005. Aras plumbum darah dan faktor-faktor yang mempengaruhi dikalangan pekerja kilang pembuat bateri. Jabatan kesihatan masyarakat, 2005 Jilid II

Bashir R, et al. (2010). Effect of Body Mass Index on Serum Cystatin C in Healthy Subjects. Pak J Med Health Sci oct-dec, 4(4):392-396.

Clark, et al. 2009. Lead levels in new enamel household paints from Asia. Africa and South America Environmental Research, 109: 930-936.

Hasan., dkk. 2013. Pengaruh jenis kelamin dan kebiasaan merokok terhadap kadar timbal darah. Jurnal Kesehatan Masyarakat Nasional : $8(4)$

Laila., 2012. kadar timbal darah dan keluhan kesehatan pada operator wanita spbu. Jurnal Kesehatan Reproduksi, 1(4) : 41-49

Lubis, dkk. 2013. Hubungan keracnan timbal dengan anemia defisiensi besi pada anak. Jurnal CDK 40 (1)

Mifbakhuddin., 2007. Hubungan kadar pb dalam darah dengan profil darah Pada petugas operator stasiuin pengisian bahan bakar umum di kota semarang timur.jurnal kesehatan masyarakat indonesia, 4(2)

Malaka, Iryani., 2012. Hubungan kadar timbeldalam darah dengan kadar hemoglobin dan hematokrit pada petugas pintu tol jagorawi. 
Jurnal kesehatan masyarakat vol 6(1).

Muntner P, et al. 2008. Overweight and Obesity and Elevated Serum Cystatin C Levels in US Adults. AnJ.Med, 121(4):341-348.

Nurbaya, Wijayanti., 2010. Faktor risiko yang berhubungan dengan timah hitam dalam darah. Kemas 6 (1) : 51-56

Naour $\mathrm{N}$ et al. 2009. Potential Contribution of Adipose Tissue to Elevated Serum Cystatin C in Human Obesity. Obesity, 17(12):21212125.

Palar, Heryando. 2012. Pencemaran dan Toksikologi Logam Berat. Rineka Cipta, Jakarta

Rustanti, Mahawati.. 2011. Faktor-faktor yang berhubungan dengan kadar timbal dalam darah pada sopir angkutan umum jurusan karang ayu-penggaron di kota Semarang. Jurnal Visikes vol 10 (1)

Riskiawati., $\backslash$ 2012. faktor-faktor yang berhubungan dengan kadar hemoblobin (Hemoglobin) dalam darah pada tukang becak di pasar mranggen demak. Jurnal kesehatan masyarakat, 2(1) : 663-669

Sudarmaji, Corie, Mukono. 2006. Toksikologi logam berat B3 dan dampaknya bagi kesehatan. Jurnal kesehatan lingkungan 2(2): 129-142

Spivey A. 2007. The weight of lead: effects add up in adults. Environmental Health Perspectives.;115(11):A31-A36.

Yulaipi, Aunurohim. 2013. Bioakumulasi logam berat timbal $(\mathrm{Pb})$ dan hubungannya denganlaju pertumbuhan ikan mujair (oreochromis mossambicus). Jurnal sains dan semi pormits 2(2): 2337-3520

Yuliningsih. 2010. Paparan Plumbum (Pb) pada pekerja bengkel sepeda motor dan dampaknya terhadap kadar $\mathrm{Pb}$ darah, $\mathrm{Hb}$ darah dan tekanan darah. 2010. (internet) [cited 2015 April]. Available from: library@lib.unair. ac.id.

Zoccali C. 2009. Overweight, Obesity and Metabolic Alterations in Chronic Kidney Disease. Biol. Med. Sci, XXX(2):17-31. 